\title{
Co-operative prey capture and unusual brooding habits of Anasterias rupicola (Verrill) (Asteroidea) at sub-Antarctic Marion Island
}

\author{
W. O. Blankley* and G. M. Branch \\ Department of Zoology, University of Cape Town, Rondebosch 7700, South Africa
}

\begin{abstract}
The asteroid Anasterias rupicola and the limpet Nacella delesserti dominate shallowwater communities around sub-Antarctic Marion Island; the limpet is the most important prey species for the starfish. A. rupicola can feed solitarily but often feeds in aggregations, particularly on large prey. This cluster-feeding allows it to capture prey otherwise unattainable because of their size, a fact of particular importance for smaller starfish. $N$. delesserti reaches a size where it is immune to predation by solitary starfish but even the largest limpets can be captured and consumed by starfish groups. Thus co-operative prey capture overcomes the normal prey size limits. A. rupicola also broods its eggs and young and is unusual in feeding on prey while still carrying brooded young. These unusual features may be related to the extremely isolated nature of the starfish's habitat, to its very slow growth and high longevity, and to its low incidence of brooding.
\end{abstract}

\section{INTRODUCTION}

Studies on starfish feeding habits are frequent. Sloan (1980) has reviewed the major findings. However there is still a need to advance our knowledge of the complexity of starfish ecology and behaviour, and Sloan encourages further work on a global scale.

Ecological studies on the littoral communities of subAntarctic islands, initiated in recent years (De Villiers, 1976; Simpson, 1976; Blankley, 1982), have revealed that echinoderms and molluscs, particularly starfish and limpets, play important roles in these communities. The present study concerns the interaction between the limpet Nacella delesserti (Philippi) and the starfish Anasterias rupicola (Verrill). Both are dominant members of the shallow inshore community of sub-Antarctic Marion Island $\left(46^{\circ} 56^{\prime} \mathrm{S}, 37^{\circ} 45^{\prime} \mathrm{E}\right)$, where the study was based. Marion Island is a volcanic island of relatively recent origin and McDougall (1971) estimates that the island is less than $300000 \mathrm{yr}$ old.

During work on a broader study of the food web in the shallow subtidal zone at Marion Island (Blankley, 1982) it became apparent that Anasterias rupicola dis-

\footnotetext{
- Present address: Department of Sea Fisheries, P. O. Box 394, Lüderitz 9000, South West Africa/Namibia
}

plays a surprising amount of gregarious behaviour in its feeding habits. True social behaviour does not occur in echinoderms, although the tendency to aggregate is a general characteristic of the phylum (Reese, 1966). Such aggregations are proposed to be the summation of individuals' reactions to environmental stimuli (Reese, 1966), mostly in response to feeding and reproductive cues (Feder and Christensen, 1966; Binyon, 1972; Sloan, 1979). In this paper we describe patterns of group behaviour in A. rupicola which show that this starfish is capable of co-operative prey capture - a phenomenon not previously described for asteroids, and with important implications for predator-prey interactions. In addition, we report the method of eggbrooding in this species; this too is different from the normal pattern displayed by asteroids.

\section{MATERIAL AND METHODS}

The main study site for work on Anasterias rupicola was Transvaal Cove, a $250 \mathrm{~m}$ length of relatively sheltered rocky boulder-bay, on the north-east coast of Marion Island. Field work was undertaken between May 1979 and May 1980. Intertidal and subtidal zones were systematically searched to a depth of $8 \mathrm{~m}$ (using 
snorkelling and SCUBA gear when necessary), and all starfish found feeding were collected together with their prey. The maximum diameter of each starfish and the length of its prey were recorded.

Brooding starfish were collected whenever seen and the diameter of the parent and the diameters and numbers of young were recorded. To determine whether Anasterias rupicola can feed while brooding, 1 brooding starfish and 10 limpets (Nacella delesserti) were placed in a cage in the subtidal zone. The cage was constructed from a $25 \mathrm{~cm}$ length of PVC piping, 10 $\mathrm{cm}$ in diameter, capped with $1 \mathrm{~mm}^{2}$ stainless-steel mesh on either end, and was tied with strong nylon twine to the holdfast of a kelp (Durvillaea antarctica). The incidence of predation on the limpets and the growth of the brooded juveniles was assessed after 45 d.

\section{RESULTS}

\section{Group feeding}

We recorded 421 instances of predation by Anasterias rupicola. In 174 cases the starfish were feeding in aggregations of up to 14 individuals, each group tightly clustered around a single prey, with the cardiac stomachs of almost all the starfish everted over the prey so that they simultaneously digested the food. We refer to such behaviour as cluster-feeding, to distinguish it from predation by isolated starfish or solitary feeding.

By introducing a large limpet to a starfish in an area densely populated by Anasterias rupicola of between 5 and $70 \mathrm{~mm}$, it was possible to observe feeding clusters more closely in the field. Other starfish joined the original captor within 20 min so that 2 or 3 starfish eventually became involved in the capture of the limpet. Nine to 14 starfish usually joined the initial group within $12 \mathrm{~h}$, and it took the starfish 48 to $96 \mathrm{~h}$ to digest completely a large limpet, after which the group dispersed.

The incidence of cluster-feeding increased with the size of the prey species, and it was most frequent on the abundant limpet Nacella delesserti, which is the largest of the prey species and attains a shell-length of $67 \mathrm{~mm}$ (Blankley, 1982). Of the 179 records of Anasterias rupicola preying on $N$. delesserti, 117 involved 2 or more starfish on the same limpet.

Although solitary Anasterias rupicola do feed on Nacella delesserti, under these circumstances their predation is size-limited, smaller A. rupicola only being able to capture small limpets (Fig. 1A). On 7 occasions solitary starfish were observed in the field attempting to capture limpets larger than themselves, but in every instance this resulted in the limpet evad- ing capture, usually by retreating rapidly up a vertical surface. While progressively larger starfish are able to capture larger limpets, in none of the 62 recorded cases was a solitary starfish found feeding on a limpet with a shell length exceeding 0.8 times the diameter of the starfish. Not only is there an upper limit to the size of limpets that can be captured by solitary A. rupicola, but larger starfish appear to select larger limpets and ignore smaller specimens, so that there is a lower limit to the size of limpets taken by large starfish (Fig. 1A). A significant linear regression relates limpet shelllength $(\mathrm{y})$ to the diameter of solitary starfish $(\mathrm{x})$ feeding on them $\left(\mathrm{y}=1.095 \mathrm{x}-27.45 ; \mathrm{n}=62 ; \mathrm{r}^{2}=0.39 ; \mathrm{p}<\right.$ $0.01)$.

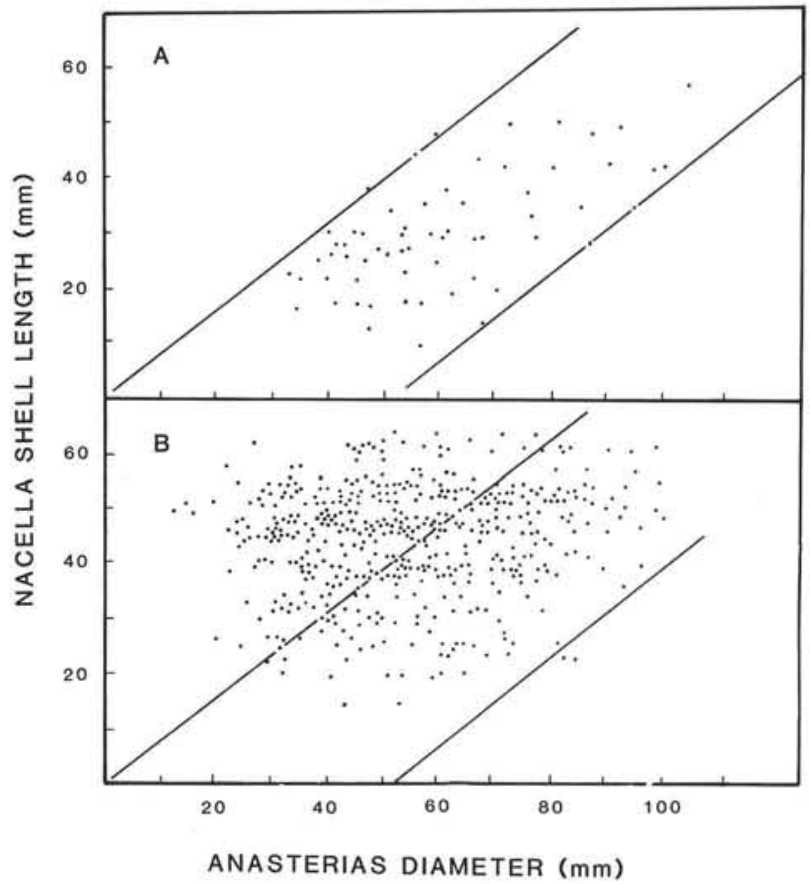

Fig. 1. Relation between (A) diameters of solitary starfish and shell lengths of limpets on which they were feeding; upper and lower limit lines fitted by eye to encompass the largest and smallest sizes of limpets preyed on by a starfish of any given diameter; upper line constrained to pass through origin; (B) size of Anasterias rupicola feeding in clusters and shell length of Nacella delesserti on which they were preying; upper and lower size limits of $N$. delesserti eaten by

solitary starfish (from Fig. 1a) inserted for comparison

In contrast to this, many of the starfish feeding in clusters were smaller than the limpets on which they were feeding (Fig. 1B). This implies that smaller Anasterias rupicola are able to overcome successfully the limitation of feeding only on small limpets by joining other starfish and feeding collectively on large limpets. When the starfish are cluster-feeding, there is no significant regression or correlation between the size of limpets and their starfish captors $\left(\mathrm{r}^{2}=0.10 ; \mathrm{p}>0.05\right)$. 
This is largely because smaller starfish are no longer restricted to eating smaller limpets.

At first sight this seems a simple case of small starfish capitalising on larger Anasterias rupicola which had captured the large prey. In part this is true, and comparison of Fig. $1 \mathrm{~A}$ and $\mathrm{B}$ shows the trend for smaller rather than larger starfish to join feeding clusters. There are, however, 3 features that make group feeding a more significant phenomenon. Firstly, in 18 of the 117 cases of group-feeding, all the starfish participating were smaller than the limpet on which they were feeding. Had they been feeding individually, they would have been incapable of capturing the limpet, but by acting in concert they were obviously able to capture larger prey which would otherwise have been unavailable to them. Only by collective effort could the small starfish have captured the large prey. On 2 occasions such behaviour was observed in the field. In each case a small starfish attempted to capture a limpet larger than itself. The limpet escaped by moving up the boulder on which it was situated, only to encounter 2 other starfish. Retreating backward the limpet was followed by all 3 starfish which converged on it and simultaneously captured the limpet. In both instances, all the starfish were too small to have captured the limpet on their own.

Secondly, starfish less than $33 \mathrm{~mm}$ in diameter are incapable of capturing limpets on their own (Fig. 1A); for these starfish group-feeding is the only means of feeding on limpets, which are by far the most important prey in terms of biomass (Blankley, 1982).

Finally, the largest limpet recorded being eaten by a solitary starfish was $57 \mathrm{~mm}$ in length (Fig. $1 \mathrm{~A}$ ), while groups of starfish feed on limpets as large as $67 \mathrm{~mm}-$

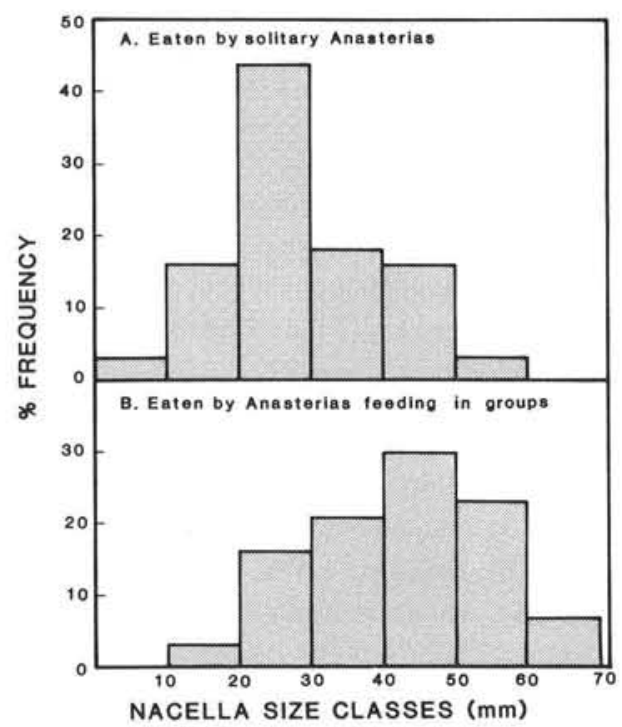

Fig. 2. Comparison of size frequencies of Nacella delesserti eaten by (A) solitary Anasterias rupicola, (B) clusters of the starfish

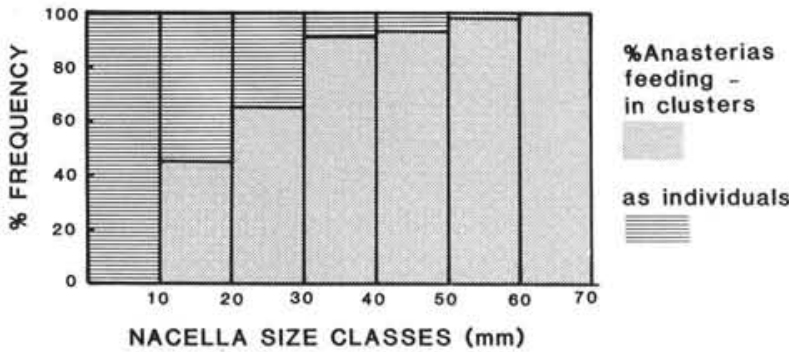

Fig. 3. Relative frequency with which Anasterias rupicola feeds on the limpet Nacella delesserti in clusters, in relation to limpet size

the largest size the limpets attain. This difference is even more striking if one averages the sizes of the 5 largest limpets captured by solitary Anasterias rupicola $(\overline{\mathrm{x}} 48.7 \mathrm{~mm}$ ) and compares this with the mean size of the 5 largest being eaten by aggregations of starfish ( $\overline{\mathrm{x}} 63.4 \mathrm{~mm})$.

Further evidence for the advantage of cluster-feeding was provided by comparing the sizes of limpets captured by groups with those consumed by solitary starfish. The modal size of limpets attacked by solitary starfish -20 to $30 \mathrm{~mm}$ - is substantially less than that for limpets preyed on by clusters of starfish -40 to 50 $\mathrm{mm}$ (Fig. 2A and B). There is also a significant difference between the mean shell length of limpets eaten by solitary Anasterias rupicola $(30.57 \mathrm{~mm})$ and by starfish in groups $(41.50 \mathrm{~mm}) ; \mathrm{t}=6.18 ; \mathrm{p}<0.001$. Limpets less than $10 \mathrm{~mm}$ in length are only eaten by solitary starfish (Fig. 3). Conversely, limpets over 60 $\mathrm{mm}$ are only eaten by groups of A. rupicola, and between these two extremes there is a gradation, with an increasingly greater proportion of limpets from the larger size classes being eaten by groups of starfish.

\section{Brooding}

During winter (Jun, Jul, Aug) Anasterias rupicola females were found brooding eggs. These broods consisted of a spherical mass of up to 358 yolky eggs 1.10 to $2.10 \mathrm{~mm}$ in diameter held under the stomach opening by the surrounding tube feet. The eggs were held together by a membraneous sheet to which each egg was attached by a thread. By November (early summer), fully recognizable young starfish had developed within these broods, but up to $28 \%$ had lost their attachment threads although they remained in the brood until December or January when broods started to decline in size as juveniles moved away. Some young remained longer and 2 females were found in March and April respectively with broods of 6 and 4 remaining juveniles. The entire brooding process thus taking from 6 to 9 mo to complete. Although the sex 


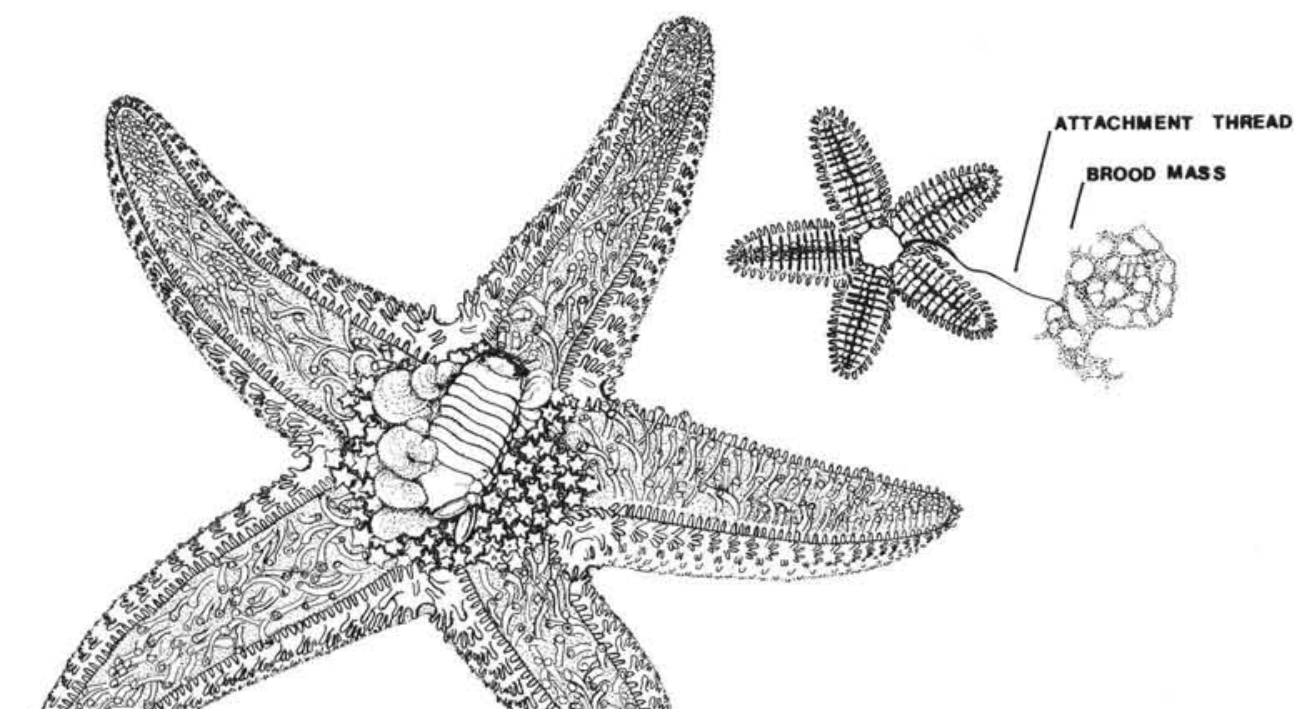

Fig. 4. Oral view of female starfish enveloping the isopod Dynamenella huttoni in her stomach whilst brooding young. The 6-mo-old young are at an advanced stage of development. Most have already left the female, but those that remain are still connected to the brood sheath via attachment threads (see inset)

ratio in A. rupicola is unity, only 30 brooders were found amongst the 2800 specimens collected, suggesting that brooding is a relatively infrequent event and certainly does not occur annually.

Of particular interest is the fact that 6 of the 30 brooding individuals were collected while feeding. One of these is illustrated in Fig. 4. Since the average incidence of predation of non-brooding Anasterias rupicola is $11.7 \%$ (Blankley, 1984), the $20 \%$ incidence of predation in the brooders suggests that they feed at least as frequently as non-brooding individuals.

Since brooding starfish were seldom encountered, it was impossible to establish properly replicated experiments to test the rate at which brooders feed. However, a single brooding starfish with about 150 young was caged in a subtidal zone for $45 \mathrm{~d}$; she devoured 8 of the 10 Nacella delesserti enclosed in the cage with her. This represents an intake of $0.605 \mathrm{~kJ} \mathrm{~d}^{-1}$, compared to the mean intake of $1.142 \mathrm{~kJ} \mathrm{~d}^{-1}$ by a similar stage nonbrooding starfish (Blankley, 1982). During the $45 \mathrm{~d}$, the mean diameter of the juveniles increased from 3.0 to $3.6 \mathrm{~mm}$ and all were free-living in the cage by the end of the experiment.

\section{DISCUSSION}

The findings presented here record unusual asteroid behaviour and habits which are unique among starfish. Sloan (1980) provides a comprehensive review of the feeding biology of asteroids and although 23 species of asteroids have been noted to form aggregations, mostly in relation to feeding activities, none is reported to feed in the discrete groups found in Anasterias rupicola. Although Anger et al. (1977) suggest that groups of $A$. rubens may successfully attack a bivalve (Cypridina islandica) too large for solitary individuals to feed on, in no case has it been demonstrated that by feeding in groups starfish can capture prey not available to solitary conspecifics. Sloan (1980) records only a few examples where starfish have been observed feeding on prey larger than themselves. The most striking of these is the observation that Odontaster validus can successfully attack another starfish, Acodontaster conspicuus, which is 20 times its size (Dayton et al., 1974). Solitary $O$. validus climb onto the aboral surface of $A$. conspicuus and begin digesting it. Other $O$. validus and large nemerteans are then attracted, possibly by release of coelomic fluid from the prey, until the entire prey is digested. Paine's (1976) paper on predation of the mussel Mytilus californianus by the asteroid Pisaster ochraceus is well known for its clear illustration that the mussel can attain a size above which it is immune to predation by $P$. ochraceus. Many other examples are known in which prey species attain a refuge from predation by $P$. ochraceus. Many other examples are known in which prey species attain a refuge from predation by virtue of their size (e.g. Menge and Menge, 1974; Kohn and Nybakken, 1975; Leviten, 1976; Bertness, 1977; Elner and Hughes, 1978; Griffiths and Seiderer, 1980).

Predation is a powerful selective agent, and escape 
through increasing body size has important evolutionary consequences. In the present case, predation of Nacella delesserti by solitary Anasterias rupicola is size-limited, and the largest $N$. delesserti are immune to predation by solitary $A$. rupicola. However, $A$. rupicola can feed in groups, thus circumventing this limitation. Small starfish can feed on large prey if they join clusters, and in groups they may capture even the largest of limpets, which would otherwise be free from predation by the starfish.

It is unlikely that the co-operative habits of Anasterias rupicola constitute truly social or purposeful behaviour. Nevertheless the most significant finding of the present study is that small starfish are able to gather in a group and collectively feed on a large animal which would have been impossible for an individual starfish to capture. The result is that an ecological barrier is lifted because a number of individuals act as a unit in capturing and consuming the same prey item.

True brooding starfish are fairly common in the higher latitudes, chiefly in the southern hemisphere and Hyman (1955) states that female starfish do not feed while brooding young. However, O'Brien (1976) has suggested that brooding female Leptasterias littoralis may feed on fine particulate material and brooding Leptasterias hexactis, $L$. pusilla and $L$. tenera have occasionally been found with ingested prey (Osterud, 1918; Menge, 1974; Smith, 1981; Hendler and Franz, 1982). In the present study, however, Anasterias rupicola was shown to be an active predator at least in the later stages of brooding, feeding as frequently as do non-brooding A. rupicola. Thus it seems that $A$. rupicola is unusual in feeding while brooding. Simpson (in press) records that at Macquarie Island $A$. directa and A. mawsoni carry external broods for 6 to 8 mo but he does not suggest that the mother may feed during this lengthy period. On the other hand, Simpson (1976) also noted that $A$. directa and A. mawsoni form feeding clusters on their largest molluscan prey, although he dismissed this finding on the basis that not all the starfish in the group had extruded stomachs. It seems at least possible that these 2 species of Anasterias also feed in a manner comparable to A. rupicola and that the 'unusual' behaviour described for $A$. rupicola will be found in other species.

The conventional explanations why many starfish (and other invertebrates) brood their young in the colder waters of high latitudes are, firstly, that planktonic food is only available for a short period and, secondly, that the low temperatures slow growth and expose planktonic larvae to predation for longer periods (Thorson, 1950; Mileikovsky, 1971; Vance, 1973). In sub-Antarctic littoral or shallow-water species, however, brooding has an additional advan- tage because there are only a small number of widely separated islands available for colonization. The production of a small number of viable young at a location where a parent has succesfully grown to maturity ensures a steady supply of local recruits. The very lengthy brooding periods of Anasterias rupicola (6 to $9 \mathrm{mo}$ ) indicates the extent of energy expended on this reproductive mode. In a previous study of A. rupicola (Blankley, 1984) it is suggested that this species is very slow-growing and lives an extremely long life. Monthly measurements of well-fed, caged A. rupicola and records of the growth rate of brooded juveniles indicate that this species lives for at least $39 \mathrm{yr}$, if not longer.

Starfish and limpets appear to dominate the shallow subtidal invertebrate communities of sub-Antarctic islands (Simpson, 1976; Blankley, 1982) and the shallow subtidal zone of Marion Island is dominated by Anasterias rupicola and the limpet Nacella delesserti. This limpet contributes $90 \%$ of the biomass of prey species that are available to A. rupicola (Blankley, 1984). N. delesserti achieves its maximum size in 6 to 8 $\mathrm{yr}$, and its relatively fast growth rate means that the limpets will outgrow the slower-growing $A$. rupicola. For these smaller A. rupicola, cluster-feeding and cooperative prey capture represent important means of overcoming this limitation and supplementing their diet of other smaller and less abundant prey species.

Acknowledgements. We thank Professor R. T. Paine for encouragement and Vanessa Moore for artwork. Research was funded by the Department of Transport as advised by the South African Scientific Committee for Antarctic Research.

\section{LITERATURE CITED}

Anger, K., Rogal, U., Schriever, G., Valentin C. (1977). In situ investigation on the echinoderm Asterias rubens as a predator of soft-bottom communities in the western Baltic Sea. Helgoländer wiss. Meeresunters. 29: 439-459

Bertness, M. D. (1977). Behavioural and ecological aspects of shore-level size gradients in Thais lamellosa and Thais emarginata. Ecology 58: 80-96

Binyon, C. (1972). Physiology of echinoderms. Pergamon Press, Oxford

Blankley, W. O. (1982). The intertidal and shallow subtidal food web of sub-Antarctic Marion Island. M. Sc. thesis, University of Cape Town, South Africa

Blankley, W. O. (1984). Ecology of the starfish Anasterias rupicola at Marion Island (Southern Ocean). Mar. Ecol. Prog. Ser. 18: 131-137

Dayton, P. K., Robilliard, G. A., Paine, R. T., Dayton, L. B. (1974). Biological accommodation in the benthic community at McDuro Sound, Antarctica. Ecol. Monogr. 44: 105-128

De Villiers, A. F. (1976). Littoral ecology of Marion and Prince Edward Islands (Southern Ocean). S. Afr. J. Antarct. Res. 1 (Suppl.): 1-40 
Elner, R. W., Hughes, R. N. (1978). Energy maximisation in the diet of the shore crab. Carcinus maenas. J. Anim. Ecol. 47: $103-116$

Feder, H. M., Christensen, A. M. (1966). Aspects of asteroid biology. In: Boolootian, R. A. (ed.) Physiology of Echinodermata. Interscience, New York, p. 87-127

Griffiths, C. L., Seiderer, J. L. (1980). Rock lobsters and mussels: limitations and preferences in predator prey interactions. J. exp. mar. Biol. Ecol. 44: 95-109

Hendler, G., Franz, D. R. (1982). The biology of a brooding seastar, Leptasterias tenera, in Black Island Sound. Biol. Bull. mar. biol. Lab., Woods Hole 162: 273-289

Hyman, L. H. (1955). The invertebrates, Vol. IV, Echinodermata. McGraw Hill, New York

Kohn, A. J., Nybakken, J. A. (1975). Ecology of Conus on eastern Indian Ocean fringing reefs: diversity of species and resource utilisation. Mar. Biol. 2: 346-359

Leviten, P. J. (1976). The foraging strategy of vermivorous gastropods. Ecol. Monogr. 46: 157-178

McDougall, I. (1971). Geochronology in Marion and Prince Edward islands. In: Van Zinderen, Bakker, E. M., Winterbottom, J. M., Dyer, R. A. (ed.) Marion and Prince Edwards islands. A. A. Balkema, Cape Town, p. 369-408

Menge, B. A. (1974). Effects of wave action and competition on brooding and reproductive effort in a rocky intertidal starfish, Leptasterias hexactis. Ecology 55: 84-93

Menge, B. A., Menge, J. L. (1974). Prey selection and foraging period of the predaceous rocky intertidal snail, Acanthina punctulata. Oecologia (Berl.) 17: 293-316

Mileikovsky, S. A. (1971). Types of devolopment in marine bottom inverbrates, their distribution and ecological significance: a re-evaluation. Mar. Biol. 10: 193:213

O'Brien, F. X. (1976). Some adaptations of the seastar Leptasterias littoralis (Simpson) to life in the intertidal zone. Thalassia jugosl. 12: 237-243

Osterud, H. L. (1918). Preliminary observations on the development of Leptasterias hexactis. Publs Puget Sound mar. biol. Stn 2: 1-15

Paine, R. T. (1976). Size-limited predatiton: an observational and experimental approach with the Mytilus-Pisaster interaction. Ecology 57: 858-873

Reese, E. S. (1966). The complex behaviour of echinoderms. In: Boolootian, R. A. (ed.) Physiology of Echinodermata. Interscience, New York, p. 157-217

Simpson, R. D. (1976). Physical and biotic factors limiting the distribution and abundance of littoral molluscs on Macquarie island (Subantarctic). J. exp. mar. Biol. Ecol. 21: $11-49$

Simpson, R. D. (in press). The reproduction of some echinoderms from MacQuarie Island. Aust. Mus. Mem.

Sloan, N. A. (1979). Starfish encounters: an experimental study of its advantages. Experientia 35: 1314-1315

Sloan, N. A. (1980). Aspects of the feeding biology of asteroids. Oceanogr. mar. Biol. A. Rev. 18: 57-124

Smith, R. H. (1981). Reproductive biology of a brooding seastar Lepasterias pusilla (Fisher), in the Monterey Bay Region. Ph. D. Dissertation, Standford University

Thorson, G. (1950). Reproduction and larval ecology of marine bottom invertebrates. Biol. Rev. 25: 1-45

Vance, R. R. (1973). On reproductive strategies in marine benthic invertebrates. Am. Nat. 107: 339-352

This paper was submitted to the editor; it was accepted for printing on July 4, 1984 